Arch. Environ. Contam. Toxicol. 16, 333-341 (1987)

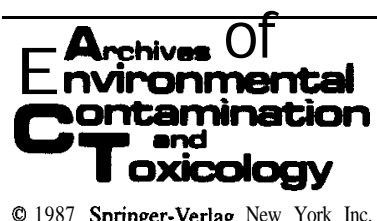

(C) 1987 Springer-Verlag New York Inc.

\title{
Suitability of Hardwoods Treated with Phenoxy and Pyridine Herbicides for Use as Firewood
}

\author{
P. B. Bush ${ }^{1}$, D. G. Neary, C. K. McMahon and J. W. Taylor, Jr. \\ University of Georgia, Athens, Georgia 30605, USDA Forest Service, Gainesville, Florida 32611, USDA Forest Service, Macon, \\ Georgia 31020, and USDA Forest Service, Atlanta, Georgia 30367
}

\begin{abstract}
Potential exposure to pesticide residues resulting from burning wood treated with phenoxy and pyridine herbicides was assessed. Wood samples from trees treated with 2,4-D [2,4-dichlorophenoxy acetic acid], dicamba [3,6-dichloro- $o$ anisic acid], dichlorprop [2-(2,4-dichlorphenoxy) propionic acid], picloram [4-amino-3,5,6-trichloropicolinic acid], and triclopyr (3,5,6-trichloro-2-pyri dinyl)oxy acetic acid contained variable amounts of parent compound residues at 4,8 , and 12 months after application. At the time of the latter sampling, residues of 2,4-D, dicamba, and picloram were $<2.1 \mathrm{mg} / \mathrm{kg}$ on a fresh weight basis. Mean residue concentrations of triclopyr and dichlorprop were somewhat higher at 3.5 and $13.0 \mathrm{mg} / \mathrm{kg}$, respectively. In a laboratory experiment, samples with known amounts of herbicide residue were subjected to either slow or rapidly burning conditions in a tube furnace. During slow combustion, relatively stable compounds such as 2,4-D, dicamba, and dichlorprop were released in significant amounts. Rapid combustion greatly enhanced decomposition of 2,4-D, dicamba, dichlorprop, picloram, and triclopyr. A well-developed fire in a wood stove or fireplace, with active flaming combustion, where temperatures commonly reach $800-1,000^{\circ} \mathrm{C}$, should result in greater than $95 \%$ thermal decomposition of the herbicides examined in this study. Burning of herbicide-treated wood under smoldering conditions could result in very low levels of herbicide residue in ambient indoor air. However, the exposure levels are less than
\end{abstract}

1 Address correspondence to: Parshall B. Bush, Extension Pesticide Residue Laboratory, 110 Riverbend Road, Athens, GA 30605 .
$0.3 \%$ of the threshold limit value for 2,4-D and triclopyr. The exposure is also more than 3 orders of magnitude lower than the established acceptable daily intakes for these products.

In the late 1970's, rising fossil fuel costs created a large demand for alternative home heating sources. Many households in the United States turned to wood as a primary or supplementary energy source. In metropolitan areas, wood typically sells for up to $\$ 200$ per cord.

One common source of firewood has been poor quality hardwoods left over from forest management practices, especially hardwoods killed by herbicides during site preparation or release projects.

Although there are several comprehensive summaries on the fate of forestry pesticides in the environment, there is little information on the fate of these chemicals when they are burned (Ghassemi et al. 1981; USDA Forest Service 1984). One reason for this lack of information is that data on residue fate after burning has not been required in the pesticide registration process, since burning of pesticide treated trees has not been considered a normal end use. Limited information is available on the fate of wood preservative chemicals after burning. Much of the published data is on inorganic chemicals (McMahon et al. 1985a; Peters et al. 1983; Dobbs and Grant 1976; Watson 1958).

The combustion of woody material is a complex process, whose end products are affected by factors such as fuel moisture, fuel chemistry, temperature, atmospheric gases, and ignition source and burning rate. Under normal fireplace and woodstove conditions, combustion products are 
Table 1. Herbicide application rates and relative concentration factors in turkey oak stems, Ocala National Forest, June 1, 1982

\begin{tabular}{|c|c|c|c|c|}
\hline Herbicide & $\begin{array}{l}\text { Injection } \\
\text { spacing } \\
\mathrm{cm}\end{array}$ & $\begin{array}{l}\text { Rate per } \\
\text { injection } \\
\mathrm{ml}\end{array}$ & $\begin{array}{l}\text { Active } \\
\text { ingredient } \\
\mathrm{kg} \mathrm{ae} / \mathrm{L}\end{array}$ & $\begin{array}{l}\text { Application } \\
\text { rate relative } \\
\text { to picloram }\end{array}$ \\
\hline Dicamba & 5.0 & 1 & 0.12 & 4.0 \\
\hline 2,4-D & 7.5 & 1 & 0.46 & 11.5 \\
\hline Triclopyr & 7.5 & 1 & 0.36 & 9.0 \\
\hline $2,4-\mathrm{D}+$ Picloram & 7.5 & i & - & - \\
\hline 2,4-D & - & - & 0.12 & 3.0 \\
\hline Picloram & - & - & 0.04 & 1.0 \\
\hline Dichlorprop & 5.0 & 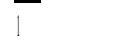 & 0.44 & 14.7 \\
\hline
\end{tabular}

vented into the outside atmosphere and only radiant heat enters the surrounding room. However, some gaseous and particulate materials can enter a room at low levels. The degree to which pesticides used in forestry could be entrained with such materials and how this type of pesticide exposure compares to standards set for occupational and ambient air is not known.

A study was undertaken in 1982 to assess the potential human exposure caused by burning herbicide-treated firewood in fireplaces and stoves. Specifically, this study sought to determine: (1) the amount of residues in herbicide-treated hardwood 4, 8, and 12 months after application, and (2) the extent of herbicide residue volatilization in combustion products under simulated stove and fireplace burning conditions. This paper examines the fate of five commonly used herbicides: (1) dicamba [3,6-dichloro-o-anisic acid], (2) dichlorprop [2-(2,4dichlorophenoxy) propionic acid], (3) picloram [4amino-3,5,6-trichloropicolinic acid], (4) 2,4-D [2,4dichlorophenoxyacetic acid], and (5) triclopyr [3,5,6-trichloro-2-pyridinyloxyacetic acid]. The potential human hazards resulting from exposure to these five herbicides under representative site conditions and simulated fireplace/stove burning conditions are addressed.

\section{Materials and Methods}

\section{Site and Treatment}

The study was established on Riverside Island of the Lake George Ranger District, Ocala National Forest, Marion County, Florida. A longleaf pine (Pinus palustris L.) stand was selected for the study site. All merchantable pines were harvested and the remaining turkey oak (Quercus laevis Walt.) and sand pine [P. clausa (Chapm. ex. Engelm.) Vasey ex. Sarg.] were scheduled for herbicide treatment prior to replanting with longleaf pine. During April and May, 1982, plots were randomly located in each of five blocks of a randomized complete block design. In each plot, 15 turkey oaks were tagged and measured (Cantrell et al. 1986). Herbicide treatments were randomly assigned to each plot. Sufficient borders were established to prevent carryover from one plot to another. The treated trees were 8 to $40 \mathrm{~cm}$ in DBH (diameter at breast height), 3 to $24 \mathrm{~m}$ high, and about 55 years old.

Treatment was completed within $24 \mathrm{hr}$ during mid-June, 1982, using herbicides listed in Table 1. Application rates were selected on the basis of label or manufacturer recommendations (Cantrell et al. 1986). Concentration factors based on the amount of acid equivalent per liter and injection spacings for a $20 \mathrm{~cm}$ diameter tree are also shown in Table 1. The five herbicides, one per plot, were injected into the base of each marked turkey oak at a rate of $1 \mathrm{ml}$ of undiluted herbicide per incision. Injections were spaced according to label specifications. A $\mathrm{Cranco}^{2}$ tubular injector with a $3 \mathrm{~cm}$ wide fluted bit was used to make the frills and injections. Each injection was applied with sufficient force to penetrate the bark and deliver herbicide into the exposed xylem.

\section{Residue Sampling From Treated Trees}

Collections of wood for herbicide residue sampling were made 4 , 8, and 12 months after application. At each sampling date, three trees per treatment were felled. A series of close-spaced chainsaw cuts were made 1 to $30 \mathrm{~cm}$ above the injection site to produce composite stem samples (bark plus wood). Trees treated with a combination of picloram and 2,4-D were sampled at 4 stem positions (base, mid-stem, top, and branches). Tissue samples were labelled, placed into plastic bags, stored in iced coolers, and transported to the University of Florida the same day for further processing and freezing. The wood samples were reduced in size by grinding in a Wiley mill to pass a $1 \mathrm{~mm}$ mesh screen and stored at $-15^{\circ} \mathrm{C}$.

\section{Residue Extraction and Q uantitation From Treated Trees}

The ground wood samples were well mixed and a subsample was extracted with acidified ethyl acetate, filtered, and concentrated with a rotary evaporator. The residue was subjected to base hydrolysis. The hydrolysate was acidified and the herbicides were

2 The use of trade, firm, or corporation names in this publication is for the information and convenience of the reader. Such use does not constitute an official endorsement or approval by the U.S. Department of Agriculture of any product to the exclusion of others that may be suitable. 
partitioned into ethyl acetate. The extract was dried over sodium sulfate, concentrated with a rotary evaporator, and the phenoxy herbicides were esterified with diazomethane reagent.

The herbicide methyl esters were quantitated by gas chromatography, using a Tracor Model 700-A electrolytic conductivity detector. The reaction furnace was set at $850^{\circ} \mathrm{C}$ with hydrogen gas flow of $70 \mathrm{ml} / \mathrm{min}$. Other operating conditions were as follows: Column $2 \mathrm{~m}$ x $4 \mathrm{~mm}$ I.D. glass packed with $3 \%$ OV-101 on Chromosorb WHP; oven temperature was programmed from $150-245^{\circ} \mathrm{C}$ at $15^{\circ} \mathrm{C} / \mathrm{min}$.; carrier gas (helium) flow of $25 \mathrm{ml} / \mathrm{min}$; and detector set at $324^{\circ} \mathrm{C}$.

Herbicide levels were quantified by comparison of sample peak heights with known analytical standards. A reagent blank and spiked wood samples were included with each set of analyses. Average recoveries of herbicide residues from ground wood fortified with herbicides ranged from 92.4 to $108.0 \%$.

\section{Combustion Procedure}

Wood samples for the laboratory combustion studies were prepared from branches taken from a locally available pesticide-free hardwood tree (swamp chestnut oak, Quercus michauxii Nutt.). The samples were oven-dried at $95^{\circ} \mathrm{C}$ until reaching equilibrium weight then ground in a Wiley mill to pass through a 20-mesh screen. The powdered wood was stored in a desiccator. Herbicide spiking solutions were prepared from formulated stock solutions using working concentrations of $2,000 \mathrm{mg} / \mathbf{L}$ parent compound. Actual spiking levels were based on chemical analysis of the working solutions.

Since no single commercial device is truly representative of all home wood burning systems, a horizontal tube furnace procedure, which is reproducible and is capable of simulating a wide range of combustion conditions, was utilized. The tube furnace (Lindberg Model 54451) was fitted with a $5 \mathrm{~mm}$ diameter $\boldsymbol{x} 1.2$ $\mathrm{m}$ long quartz tube and other special fittings and sampling apparatus (McMahon et al. 1985b). This system allowed small $(0.5 \mathrm{~g})$ fuel samples to be burned under preselected combustion conditions and flow rates. It also permitted quantitative sampling of combustion gases and particulates generated during each burn. The quantity of particulate matter released was used as an indication of combustion efficiency and as an indicator of flaming (rapid) combustion and smoldering (slow) combustion. Preliminary experiments indicated that smoldering conditions could be simulated by slowly heating the sample $\left(20^{\circ} \mathrm{C} / \mathrm{min}\right)$ to $500^{\circ} \mathrm{C}$. Flaming conditions were simulated by inserting the fuel sample directly into the furnace which was preheated to $500^{\circ} \mathrm{C}$.

For idealized stoichiometric conditions, $1 \mathrm{~g}$ of wood requires approximately $6 \mathrm{~g}$ of air for complete combustion. Under actual burning conditions, both pyrolytic and oxidative decomposition occurs with the resulting release of smoke gases and particulates. In this study, an air flow of $2.8 \mathrm{~L} / \mathrm{min}$, supplied from compressed air cylinders, was maintained through the furnace. This provided both combustion air and a means to sweep the combustion products out of the furnace and into the air samplers.

The condensing particulate matter and gases were passed through a glass transfer tube (TT), a $47 \mathrm{~mm}$ inline filter holder containing a glass fiber filter (GFF), followed by two polyurethane foam plugs (PUF) (Yamasaki et al. 1982; Lewis et al. 1977; Lewis and Jackson 1982).

The PUF plugs efficiently trap pesticides while allowing a high air flow rate. No detectable levels of any phenoxy residues were found in the second PUF in the sampling train. Sample train components (TT, GFF, and PUF's) were stored in individual containers at $-4^{\circ} \mathrm{C}$ for analysis.

\section{Residue Extraction From Smoke Condensate}

Each TT, GFF, and PUF was transferred to a $125 \mathrm{ml}$ Erlenmeyer flask and $80 \mathrm{ml}$ of $1.0 \mathrm{~N}$ sodium hydroxide in $10 \%$ sodium chloride was added. The flask was placed in an $85^{\circ} \mathrm{C}$ water bath for $30 \mathrm{~min}$. and sonicated for an additional $15 \mathrm{~min}$. The extract was filtered through a glass fiber filter and transferred to a $250 \mathrm{ml}$ separatory funnel. The extract was acidified $(\mathrm{pH}=2)$ with $6 \mathrm{~N}$ sulfuric acid and additional sodium chloride was added (15 $\mathrm{g} / 100$ $\mathrm{ml}$ of extract). The acidified aqueous solution was partitioned three times with $100 \mathrm{ml}$ diethyl ether. The ether extracts were combined, dehydrated with sodium sulfate, transferred to a boiling flask, and reduced to dryness, using a rotary evaporator. The residue was methylated with diazomethane and made to a total volume of $5.0 \mathrm{ml}$ with ethyl acetate for GLC analysis.

\section{Gas Chromatographic Analysis of Smoke}

Analysis of the acidic herbicide methyl esters was performed on a gas chromatograph equipped with an electrolytic conductivity detector (halogen mode) and a $2 \mathrm{~m} \times 2 \mathrm{~mm}$ I.D. glass column packed with $3 \%$ OV-101 on Chromosorb WHP. GLC parameters were as follows: Detector $-325^{\circ} \mathrm{C}$; injector $-250^{\circ} \mathrm{C}$; detector reactor temperature $900^{\circ} \mathrm{C}$; hydrogen flow $30 \mathrm{ml} / \mathrm{min}$; solvent flow setting-4; solvent vent time $0.75 \mathrm{~min}$; helium gas carrier flow-35 $\mathrm{ml} / \mathrm{min}$; and GLC column oven temperature programmed from $150^{\circ}$ to $235^{\circ} \mathrm{C}$ at 15 degrees $/ \mathrm{min}$.

A reagent blank and fortified PUF and GFF samples were run with each set of analyses. Herbicide levels were quantified by comparing retention time and peak height of components in the sample with the analytical standards. Herbicide recovery from fresh PUF's and GFF's containing smoke condensate from the dichlorprop runs had high recovery rates $(>100 \%)$ which indicated an enhanced GLC response. The picloram pyrolysis product 2,3,5 trichlopyridine (TCP) was not recovered using this extraction procedure. Another picloram pyrolysis product, 4 amino-2,3,5 tricloropyridine (CATCP), was partially recovered $(53-62 \%)$ by the extraction procedure used for picloram.

\section{GC-MS Analysis of Pyrolysis Products}

The methylated filter extracts from a picloram pyrolysis run were analyzed on a Finnigan Model 4000 gas chromatograph/ mass spectrometer equipped with a $30 \mathrm{~m}$ DB5 capillary column (0.32 $\mathrm{mm}$ I.D.) operated in the electron impact mode. The spectra of 4-ATCP and TCP were compared with spectra of standard compounds analyzed on the same instrument.

Analytical standards of dicamba, 2,4-D, and dichlorprop were obtained from the US Environmental Protection Agency, Research Triangle Park, NC. Triclopyr, picloram, 4-aminotrichloropyridine (CATCP), and trichloropyridine (TCP) standards were obtained from Dow Chemical Agricultural Products Department, Midland, MI. All solvents used for extraction were distilled in glass (pesticide grade). Prior to use, the PUF's were Soxhlet extracted with distilled-in-glass residue-free methanol. 
Table 2. Phenoxy herbicide residues in injected turkey oak stems; mean residues in wood samples ( \pm 1 standard deviation) collected 4, 8, and 12 months after stem injection. Ocala National Forest, 1982-1983

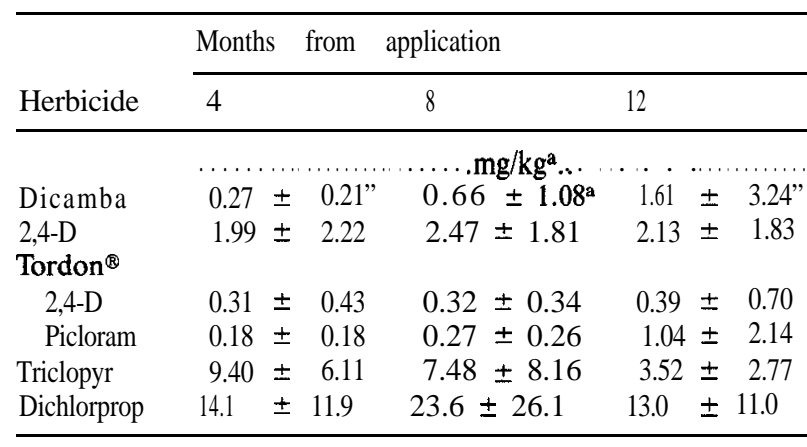

a Values are means of 5 sample \pm 1 standard deviation. Values are on wet weight basis and are not segregated by DBH (diameter at breast height) class

\section{Results and Discussion}

\section{Stem Residues}

Herbicide residues measured in samples from basal portions of the treated turkey oak generally followed concentration patterns determined by the initial treatment (Table 1). Although the volume of herbicide application per injection was the same for each chemical $(1 \mathrm{ml})$, differences in spacings between injections (5 to $7.5 \mathrm{~cm}$ ) mandated by label directions or manufacturer's recommendations and the amount of active ingredient in each herbicide formulation $(0.04$ to $0.48 \mathrm{~kg}$ ae/ $/ \mathrm{L})$ produced a gradient in relative rate of herbicide application. The relative rates listed in the last column of Table 1 were based on spacings between injections, the rate of herbicide delivered per injection, of acid equivalent of herbicide per liter, and an average tree with a DBH of $20 \mathrm{~cm}$. The rates were made relative to picloram, which had the lowest content in the herbicide formulations used for the study. The range in relative application rates from 1.0 (picloram) to 14.7 (dichlorprop) was closely reflected in the firewood residue levels (Table 2).

Turkey oak stems treated with dicamba and 2,4-D plus picloram contained less than $1 \mathrm{mg} / \mathrm{kg}$ 4,8 , and 12 months after application (Table 2). Residue levels from both 2,4-D and triclopyr applications ranged from 1.9 to $10.0 \mathrm{mg} / \mathrm{kg}$. Residues of dichlorprop were the highest throughout the 12 months ranging from 13.0 to $23.6 \mathrm{mg} / \mathrm{kg}$. Except for triclopyr, herbicide residue concentrations in the stem bases increased between the 4 and 8 month samplings. These concentration increases may be attributable to continued redistribution of residues within the stem. Moisture content data taken at each sampling indicated that there was no drying
Table 3. Picloram and 2,4-D vertical distribution in turkey oak stems 2, 4, and 8 months after herbicide application, 1982-1983

\begin{tabular}{|c|c|c|c|c|c|}
\hline \multirow[b]{2}{*}{ Date } & \multirow{2}{*}{$\begin{array}{l}\text { Period }^{a} \\
\text { (mos) }\end{array}$} & \multirow[b]{2}{*}{ Position } & Herbicide & \multicolumn{2}{|l|}{ Residues } \\
\hline & & & Picloram & 2,4-D & \\
\hline & & & \multicolumn{3}{|c|}{$\mathrm{mg} / \mathrm{kg}^{\mathrm{b}}$} \\
\hline \multirow[t]{4}{*}{$08-26-82$} & 2 & Base & $0.15(0.21)^{\mathrm{c}}$ & 0.39 & $(0.62)$ \\
\hline & & Mid & N.D..$^{d}$ & 0.02 & $(0.03)$ \\
\hline & & Upper & $0.18 \quad(0.02)$ & 0.52 & (0.74) \\
\hline & & Crown & $0.88 \quad(1.43)$ & 0.28 & (0.28) \\
\hline \multirow[t]{4}{*}{$10-22-82$} & 4 & Base & $0.11 \quad(0.13)$ & 0.24 & $(0.32)$ \\
\hline & & Mid & $0.02 \quad(0.03)$ & 0.05 & (0.03) \\
\hline & & Upper & $0.09 \quad(0.15)$ & 0.09 & $(0.03)$ \\
\hline & & Crown & $2.25(1.36)$ & 0.53 & $(0.37)$ \\
\hline \multirow[t]{4}{*}{$02-18-83$} & 8 & Base & $0.33 \quad(0.21)$ & 0.31 & $(0.33)$ \\
\hline & & Mid & $0.02 \quad(0.03)$ & N.D. & \\
\hline & & Upper & $0.02 \quad(0.03)$ & 0.01 & $(0.02)$ \\
\hline & & Crown & $0.09 \quad(0.06)$ & 0.04 & $(0.04)$ \\
\hline
\end{tabular}

a One set of samples were taken early at 2 months and the 12 month samples were lost

b Concentration on a green weight basis (ppm)

c Mean with standard deviation in parenthesis

d N.D. = non-detectable at a concentration of $0.005 \mathrm{mg} / \mathrm{kg}$

trend even at 12 months. Most samples were still in the range of 85 to $140 \%$ moisture with the bulk of the stems in the 100 to $120 \%$ range. Bush et al. (1986) reported that some oak species do not exhibit substantial drying of the stem basal wood, even 16 months after application of an effective herbicide.

Herbicide vertical distribution was checked by sampling one set of 2,4-D plus picloram-treated trees. These trees were part of the study design (Cantrell et al. 1986) but were sampled at midstem, upper stem, and crown branch positions as well as at the stem base. Two months after herbicide application, residues were higher in basal and crown branch samples than in those from intermediate positions (Table 3). This result was expected, since residues were likely to be higher adjacent to the application sites and in the crowns where herbicide molecules are actively translocated (Hay 1976). 2,4-D was applied at 3 times the rate of picloram (Table 1). This can be seen in the difference in picloram and 2,4-D concentrations (0.16 and 0.50 $\mathrm{mg} / \mathrm{kg}$, respectively) in wood from stem bases. However, crown branches sampled at 2 months had higher levels of picloram than 2,4-D. Translocation of 2,4-D and picloram within xylem tissue is highly variable from species to species (Ashton and Crafts 1981). 2,4-D concentrations in mid- and upper-stem samples averaged less than $0.02 \mathrm{mg} / \mathrm{kg}$. Picloram residues in the upper stem were slightly higher than in basal samples, but mid-stem samples did not contain detectable levels. 
Table 4. Release of acidic herbicide residues and particulate emissions from laboratory combustion experiments ${ }^{\mathrm{d}}$

\begin{tabular}{|c|c|c|c|c|c|c|}
\hline \multirow[b]{2}{*}{ Herbicide } & \multicolumn{3}{|c|}{ Slow Combustion } & \multicolumn{3}{|c|}{ Rapid Combustion } \\
\hline & $\begin{array}{l}\text { Application } \\
\text { rate } \\
(\mathrm{ppm})\end{array}$ & $\begin{array}{l}\text { Parent acidic } \\
\text { herbicide recovered } \\
\%\end{array}$ & $\begin{array}{l}\text { Particulate } \\
\text { emissions } \\
\%\end{array}$ & $\begin{array}{l}\text { Application } \\
\text { rate } \\
\text { (ppm) }\end{array}$ & $\begin{array}{l}\text { Parent acidic } \\
\text { herbicide recovered } \\
\%\end{array}$ & $\begin{array}{l}\text { Particulate } \\
\text { emissions } \\
\%\end{array}$ \\
\hline 2,4-D & $2,580(79)$ & 88.9 (13.1) & $11.2(0.5)$ & 2,590 & $1.62(1.26)$ & $1.32(0.36)$ \\
\hline $\begin{array}{l}\text { Picloram } \\
\text { 4A-TCP }\end{array}$ & $243(7.6)$ & $\begin{array}{l}0 \\
97.5(3.9)\end{array}$ & $11.2(0.5)$ & $243(6.4)$ & $\begin{array}{cc}0 & 0 \\
64.0 & (23.1)\end{array}$ & $1.32(0.36)$ \\
\hline Dicamba & $720(26)$ & $91.5(5.2)$ & $10.8(0.5)$ & $723(5.1)$ & $32.1 "(30)$ & $3.41 \quad(4.81)$ \\
\hline Dichlorprop & $400(14.2)$ & $>100^{\mathrm{b}} \quad(8.1)$ & $10.8(0.5)$ & $406(10.4)$ & $6.50(1.58)$ & $3.41 \quad(4.81)$ \\
\hline
\end{tabular}

a These relatively high recoveries are explained in the text and do not occur when the furnace is heated to $600^{\circ} \mathrm{C}$

b These high value recoveries for dichlorprop reflect an enhanced GLC response in the presence of smoke condensate

c Mean with standard deviation in parenthesis

d Herbicide-treated wood samples were heated slowly $\left(20^{\circ} \mathrm{C} / \mathrm{min}\right.$ from ambient to $500^{\circ} \mathrm{C}$ in the tube furnace) or rapidly (wood samples inserted into a tube furnace preheated to $500^{\circ} \mathrm{C}$ ) and combustion products collected. Values are mean \pm 1 standard deviation ${ }^{\mathrm{c}}$. The recovered amount of pesticide is reported as percent of that applied to the wood sample. The amount of pesticide applied is given as $\mathrm{mg} / \mathrm{kg}$ of wood on a dry weight basis

After 4 months, residues of both picloram and 2,4-D in stem base samples declined slightly (Table 3). Mid-stem and upper-stem samples were still low $(<0.09 \mathrm{mg} / \mathrm{kg})$. Residue concentrations for both herbicides increased in top branches. By 8 months, residue levels at all stem positions were on the decline with only basal samples exceeding 0.10 $\mathrm{mg} / \mathrm{kg}$. Picloram was the only exception, as its mean concentration increased from 0.18 to 0.27 $\mathrm{mg} / \mathrm{kg}$ between 4 and 8 months.

During the first 8 months after herbicide application, the highest residue concentrations were detected in branches from tree crowns. This portion of hardwood trees is usually not used for firewood fuel and normally remains on-site after the trees are felled. Mid and upper stem portions of the treated trees contained no or low-level residues of 2,4-D. One upper stem sample, at 2 months, contained slightly more picloram than the sample from the tree base. However, this concentration was still low in relative terms. Generally, the sampled portions of the tree stem bases (within $30 \mathrm{~cm}$ of the herbicide application points) had the highest herbicide residue levels. Avoiding the bottom $100 \mathrm{~cm}$ of herbicide-treated tree stems would certainly avoid the firewood with the highest herbicide residue concentrations.

Herbicide residues measured in turkey oak wood samples at any of the intervals between 4 and 12 months after application (Tables 2 and 3) never exceeded the established tolerances for food crops. These residue tolerances $(3 \mathrm{mg} / \mathrm{kg}$ for dicamba on asparagus; $5 \mathrm{mg} / \mathrm{kg}$ for 2,4-D on apples; and 5 $\mathrm{mg} / \mathrm{kg}$ for picloram in cattle) are based on oral exposure (ingestion) which results in higher systemic doses than dermal exposure from handling treated crops. Thus, handling herbicide-treated oak stems during firewood collection should not result in significant exposure or adverse effect on humans.

\section{Herbicide Carryover In Combustion Products}

Average residue and particulate emissions for each herbicide tested are presented in Table 4. Particulate emission values give a good indication of combustion efficiency. A particulate emission of $10 \%$ for the slow burn corresponds to values obtained from wood burning in wood stoves with a closed damper (Knight 1983). Particulate values resulting from rapid combustion $(<3 \%)$ correspond to values found for particulate production from wood stoves with open damper (Knight 1983) and fireplaces (Dasch 1982). They also corresponded to values found in the flaming (rapid combustion) and smoldering (slow combustion) of forest fuels such as burning pine needles (McMahon and Tsoukalas 1978). These particulate results indicate that the combustion tube furnace is simulating the wide range of desired oxidative thermal environments to be found in domestic wood stoves and fireplaces.

Table 4 shows results of test runs in which samples were subjected to a slow heating rate. Herbicide recovery from these runs ranged from 0 for picloram to greater than $100 \%$ for dichlorprop. Analytical interference caused by chemicals in wood smoke and PUF's may account for the high dichlorprop recovery. Recovery of 2,4-D and dicamba were $88.9 \%$ and $91.5 \%$, respectively. Although there was a wide range of recoveries from the slow heating treatment, recoveries among replicate runs for each herbicide were consistent. It is apparent that carryover was highly dependent on the physical properties of the herbicide under slow heating conditions. 
In order to examine the possible picloram pyrolysis products, the glass fiber filter from a picloram plus 2,4-D combustion experiment was extracted, the extract was methylated and analyzed by gas chromatography-mass spectrometry (GCMS). The three major components in the filter extract corresponded to the methyl ester of 2,4-D, 2,3,5-trichloropyridine and 2,3,5-trichloro-4-aminopyridine .

Analysis of the smoke condensate fractions (Table 4) showed that picloram is converted to 2,3,5-trichloro-4-aminopyridine (4A-TCP) during distillation (heating) and that the 4A-TCP in the smoke condensate accounts for $97 \%$ of the picloram treatment under slow burning conditions. The pyrolysis product 2,3,5-trichloropyridine is not quantitatively recovered by the picloram extraction procedure.

When wood samples are subjected to rapid combustion (inserting sample into pre-heated furnace), mean herbicide recovery ranged from $0 \%$ for picloram to about $32 \%$ for one run of dicamba. Under rapid combustion conditions, picloram is converted to $4 \mathrm{~A}-\mathrm{TCP}$, the compound which accounts for $64 \%$ of the picloram residues in the smoke. Average recovery of $2,4-\mathrm{D}$ in smoke condensate was only $1.6 \%$, which is much less than the $88.9 \%$ recovery observed under slow conditions (Table 4).

Particulate and pesticide emissions for the dicamba $(32.1 \%$ pesticide carryover with standard deviation of 30 ) and dichlorprop recovery $(6.5 \%)$ runs gave mixed results with rapid combustion. A possible explanation of these mixed results for particulate emission involves the absence or presence of flaming combustion. For slow heating, flaming combustion does not dominate. This causes emission of large quantities of particulates and herbicides. In some rapid combustion insertion runs, flaming dominated, thus efficient burning and a marked reduction of particulate emissions occurred. In other rapid heating runs, flaming did not dominate, yielding high levels of herbicide and particulate matter. Apparently, $500^{\circ} \mathrm{C}$ is a borderline condition for flaming combustion while $600^{\circ} \mathrm{C}$ consistently results in flaming combustion as evidenced by the low particulate emissions.

\section{Potential Exposure From Burning Treated Wood}

The assumptions and data presented in Table 5 were used to calculate potential exposures resulting from burning treated wood (Table 6). The assumptions inherent in the exposure calculations are based on the following: First, a fuelwood combustion rate of $3.0 \mathrm{~kg} / \mathrm{hr}$ for slow combustion in a
Table 5. Calculation of home exposure resulting from burning phenoxy and pyridine treated firewood

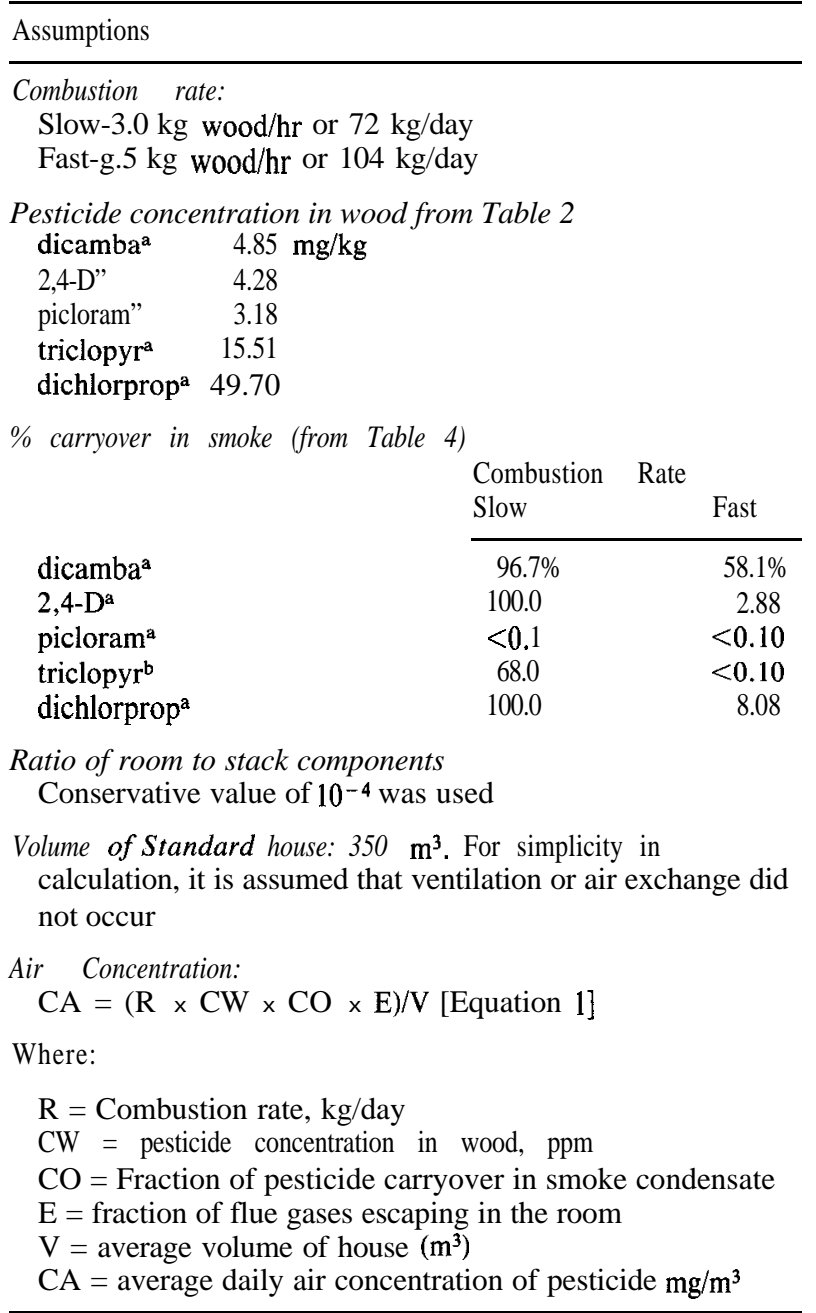

a highest measured value +1 standard deviation

b triclopyr carryover determined on combustion experiments conducted Feb 1986

woodstove and $8.5 \mathrm{~kg} / \mathrm{hr}$ rapid combustion in a fireplace (DeAngelis et al. 1980b).

Hubble and Harkness (198 1) and DeAngelis et al. (1980a) reported carbon monoxide stack concentrations between 10,00O-30,000 ppm for a wide variety of wood burning conditions. In a separate study that examined the effects of wood combustion on residential indoor air quality, Moschandreas and Zabransky (1981) reported carbon monoxide home concentrations to be elevated by approximately $1 \mathrm{ppm}$ as a result of woodburning in wood stoves and fireplaces in a residential suburban neighborhood. This suggests a rate of $1 / 10,000$ or $10^{-4}$ as a possible assumption for use in risk analysis. In this case, home ventilation and recirculation from neighbor homes, etc., is factored into the 
Table 6. Potential exposure from burning herbicide-treated wood.

\begin{tabular}{|c|c|c|c|c|c|c|}
\hline Herbicide & $\begin{array}{l}\text { Slow } \\
\text { combustion }\end{array}$ & $\begin{array}{l}\text { Fast }\left(500^{\circ} \mathrm{C}\right) \\
\text { combustion }\end{array}$ & "Adjusted" TLV & $\begin{array}{l}\text { Daily } \\
\text { exposure } \\
\text { for slow } \\
\text { combustion }\end{array}$ & AD1 & $\begin{array}{l}\mathrm{AD} 1 \\
\text { reference }\end{array}$ \\
\hline \multirow[t]{2}{*}{$(\mathrm{Col} 1)$} & $(\mathrm{Co} 12)$ & (Col 3) & $(\mathrm{Col} 4)$ & (Col 5) & (Col 6) & $(\mathrm{Col} 7)$ \\
\hline & & $\ldots \ldots 10^{-4} \mathrm{mg} / \mathrm{n}$ & & $\ldots \ldots 10^{-4} \mathrm{~m}$ & & \\
\hline Dicamba & 0.960 & 0.837 & $b$ & 0.110 & $125^{\mathrm{b}}$ & CFR (1983) \\
\hline 2,4-D & 0.880 & 0.036 & $330.0 "$ & 0.108 & $100^{c}$ & \\
\hline Picloram & $<0.001$ & $<0.001$ & $330.0 "$ & $<0.0001$ & 15,000 & USDA Forest Service \\
\hline Triclopyr & 3.134 & co.005 & $\mathrm{d}$ & 0.371 & $250^{\mathrm{c}}$ & USDA Forest Service \\
\hline Dichlorprop & 10.224 & 1.193 & $\mathrm{~d}$ & 1.256 & 1,200 & Weed Science Society 1983 \\
\hline
\end{tabular}

a Reference ACGIH 1984

' No published TLV for these herbicides, therefore no "adjusted" TLV" is listed

c Provisional acceptable daily intake (PADI)

d The values presented in Col. 2 and 3 are calculated room air concentrations of pesticides using equation 1 in Table 5. Daily exposure in col. 5 was calculated, assuming a $70 \mathrm{~kg}$ adult inhales $8.6 \mathrm{~m} /$ day with $100 \%$ systemic absorption of pesticide. If AD1 was not published it was derived by dividing the no effect level by an uncertainty factor of 100

ratio. In the case of burning herbicide-treated wood, it is unlikely that the entire community would be doing it, so $10^{-4}$ would no doubt be an extreme worst case factor and if in error it's erred on the side of safety.

Actual data on herbicide concentrations in wood and carryover are derived from Tables 2 and 4, respectively. Wood concentration values listed in Table 2 are mean values \pm 1 standard deviation. Percent carryover in smoke under slow and fast combustion conditions are also mean percent recoveries in smoke \pm 1 standard deviation. Average daily air concentrations of the herbicides were calculated using Equation 1 (Table 5). For example, the concentration resulting from the slow combustion of dicamba would be equal to: several states to estimate risk from non-criteria pollutants (DeAngelis et al. 1980b). Using the assumptions outlined in Table 5, residential concentration generated by the slow combustion of 2,4-D $(0.960$ $\mathrm{x} 10^{-4} \mathrm{mg} / \mathrm{m}^{3}$ ) is over 300 times below the "safe sided" $\operatorname{TLV}\left(1 / 300 \times 10 \mathrm{mg} / \mathrm{m}^{3}=333 \times 10^{-4} \mathrm{mg} /\right.$ $\left.\mathrm{m}^{3}\right)$.

The World Health Organization has established an acceptable human daily intake (ADI, Table 6, Col 6) for many pesticides, while the USEPA has published provisional acceptable daily intake (PADI) values for some pesticides. Acceptable daily intake for picloram and dichlorprop were calculated as: No observable effect level NOEL/ $100=\mathrm{AD} 1$ (Doull et al. 1980; NAS-NRC 1977). If we assume that a $70 \mathrm{~kg}$ adult would inhale $8.6 \mathrm{~m}^{3} /$

\begin{tabular}{|c|c|c|c|c|c|}
\hline $\begin{array}{l}\text { Burn } \\
\text { Rate }\end{array}$ & $\begin{array}{l}\text { Pesticide } \\
\text { Conc. }\end{array}$ & Carryover & $\begin{array}{c}\text { Stack/Rm. } \\
\text { Emission }\end{array}$ & $\begin{array}{l}\text { R o o m } \\
\text { Volume }\end{array}$ & $\begin{array}{l}\text { Room } \\
\text { Con. }\end{array}$ \\
\hline $72 \mathrm{~kg} /$ day & x $4.8 \mathrm{mg} / \mathrm{kg}$ & x 0.967 & X $10^{-4}$ & $\times 1 / 350 \mathrm{~m}^{3}$ & $=0.96 \times 10^{-4} \mathrm{mg} / \mathrm{m}^{3}$ \\
\hline
\end{tabular}

Estimates of possible exposure resulting from burning wood injected with phenoxy herbicide (Table 6) were developed from the data discussed in this paper and the values defined in Table 5 ( Col 2,3). The Threshold Limit Value (TLV) for 2,4-D and picloram is $10 \mathrm{mg} / \mathrm{m}^{3}$ (ACGIH 1984). The TLV is the time weighted average concentration for a normal 8-hour workday and a 40-hour workweek to which nearly all workers (usually in manufacturing) may be repeatedly exposed, day after day, without adverse effect. To convert occupational TLV's to "adjusted" TLV's (Col 4), a safety factor of 300 was used. This is consistent with methodology used by the U.S. Environmental Protection Agency and day (Ganong 1979) and 100\% pesticide absorption by the body, then potential human exposures (i.e., the quantity of pesticide absorbed systemically each day) can be estimated (Table 6, Col 5). We used average air concentration generated under slow burning conditions (Table 6, Col 2) to simulate maximum residue production conditions.

Comparing the residues produced under conditions of maximum carryover (slow combustionCol 2, Table 6), to the "adjusted" TLV for 2,4-D shows that the potential exposure to pesticide residue is lower than the adjusted TLV by a factor of 1,000 . The same is true for picloram, except the potential exposure is less than the adjusted TLV by a 
factor greater than 50,000 assuming $8 \mathrm{~m}^{3} /$ day inhalation. The available toxicological data for the picloram pyrolysis product $4 \mathrm{~A}-\mathrm{TCP}$ is insufficient to generate TLV or AD1 levels. When potential daily exposures from burning treated wood (Table $6, \mathrm{Col} 5$ ) are compared to PADI's or ADI's for those herbicides (Table 6, Col 6), it is apparent that potential inhalation exposures are $>100$ times lower than acceptable daily intake. Thus, the safety factor is high and the exposure risk from burning herbicidetreated wood is very low.

\section{Conclusions}

Stem injection at the root collar with phenoxy herbicides resulted in low residue levels $(<10 \mathrm{mg} / \mathrm{kg})$. Most residues were $<5.0 \mathrm{mg} / \mathrm{kg}$ in wood tissue 4,8 , and 12 months after injection. Since residue levels in firewood resulting from stem injection were below tolerances for forage intended for cattle feed they should not pose a health risk when the treated firewood is handled. Direct spray applications of phenoxy herbicides may, however result in higher residue levels on bark or exposed wood surfaces of treated trees.

During the slow combustion process, the amount of pesticide released depends on the physical and thermal properties of the compound. Relatively stable compounds such as 2,4-D, dichlorprop and dicamba, as well as compounds with higher or lower vapor pressures are released. Thermally unstable compounds such as picloram decompose readily under both slow and rapid combustion.

Under conditions of rapid flaming combustion, 2,4-D, dicamba, dichlorprop, picloram and triclopyr decomposed readily, with high temperatures causing almost complete decomposition. A well ventilated, fully, developed fire in a wood stove or fireplace where temperatures can reach 800$1000^{\circ} \mathrm{C}$ can produce virtually complete decomposition of most common phenoxy herbicides.

Fires producing incomplete combustion (temperatures $<500^{\circ} \mathrm{C}$ ) can result in the evolution of trace pesticide residues in smoke and combustion gases. However, the levels of herbicide residue evolved and potentially absorbed systemically are well below ( $>\mathbf{3}$ orders of magnitude) AD1 levels that are judged by regulatory agencies to be safe to ingest on a daily basis.

Acknowledgments. The authors wish to express their sincere appreciation to The National Agricultural Pesticide Impact Assessment Program for supporting this study; and to the Administrative Staff of the Ocala National Forest for providing the site.

\section{References}

ACGZH (1984) TLV's (threshold limit values) for chemical substances in the work environment adopted by ACGIH for 1984-85. Am Conf Gov Indust Hygienists, Cincinnati, Ohio. $116 \mathrm{pp}$

Ashton FM and Crafts AS (1981) Mode of action of herbicides. John Wiley \& Sons, New York, 525 pp

Bush PB, Hendricks HL, Neary DG, McMahon CK (1986) Effect of burning on hexazinone residues in firewood. 39th Annual Southern Weed Science Society Meeting. Nashville, Tennessee 39:343-353

Cantrell RL (1984) The effects of eight herbicides on Turkey Oak; Topkill and Sprouting. MS Thesis, University of Florida

Cantrell RL, Flinchum DM, Neary DG (1986) Individual tree treatments using herbicides for control of turkey oak (Quercus laevis Walt.) South J Appl For In Press

CFR (Code of Federal Regulations) (1983) Office of the Federal Register, National Archives and Records Service, General Services Administration. Volume 42, Part 11119. Washington, DC

(1984) Food and Drugs. Office of the Federal Register, National Archives and Records Service, General Services Administration. Volume 21, Parts 170 to 199. Washington, DC

- (1984) Food and Drugs. Office of the Federal Register, National Archives and Records Service, General Services Administration. Volume 21, Parts 500 to 599. Washington, DC

(1984) Protection of Environment. Office of the Federal Register, National Archives and Records Service, General Services Administration. Volume 40, Parts 150 to 189. Washington, DC

Dasch JM (1982) Particulate and gaseous emissions from wood burning fireplaces. Environ Sci Technol 16(10):639-645

DeAngelis DG, Ruffin DS, Rezik RB (1980a). Preliminary characterization of emissions from wood-fueled residential combustion equipment. US Environmental Protection Agency, EPA 600/7-80-040, Washington, DC

DeAngelis DG, Ruffin DS, Peters JA, Rezik RB (1980b) Source Assessment: Residential combustion of wood. US Environmental Protection Agency, EPA-600/2-70-042b, Washington, DC

Dobbs AJ, Grant C (1976) Report on the burning of wood treated with wood preservatives containing copper, chromium, and arsenic. Building Research Establishment, Current Paper CP 63176, Aylesbury, Buckinghamshire, UK

Doull J, Klaasen CD, Amdur MO (1980) Toxicology. 2nd ed, Macmillan, New York. 778 pp

Ganong WF (1979) Pulmonary Function, Review of Medical Physiology. Lange Medical Publications, Los Altos, CA

Ghassemi M, Fargo L, Painter P, Quinlivan S, Scofield R, Takata A. (1981) Environmental Fates and Impacts of Major Forest Use Pesticides. TRW, Redondo Beach, California. US EPA contract 68-02-3174, NTIS PB 83-124552

Hay JR (1976) Herbicide transport in plants. In: L. J. Audos (ed) Herbicides, Vol. 1. Academic Press, New York, pp 363-396

Hubble BR, Harkness JLB (1981) Results of laboratory tests on wood stove emissions and efficiency in: Proceedings on Wood Combustion, Environmental Assessment, New Orleans, Feb. 1981, US EPA 100/9-81-029, Ayer FA (ed) Washington, DC

Knight CV (1983) New technology versus conventional airtight 
wood heater emissions. pp. 478-488 in A Speciality conference on Measuring and Monitoring of Non-criteria (Toxic) Contaminants in Air. APCA Special Pub. 50, Air Pollut Control Assoc, Pittsburgh, PA

Lewis RG, Brown AR, Jackson MD (1977) Evaluation of polyurethane foam for sampling of pesticides, polychlorinated biphenols, and polychlorinated naphthalenes in ambient air. Anal Chem 49: 1668- 1672

Lewis RG, Jackson MD (1982) Modification and evaluation of a high-volume air sampler for pesticides and semivolatile industrial organic chemicals. Anal Chem 54:592-595

Moschandreas DJ, Zabransky J (1981) Residential indoor air quality and wood combustion. In: Ayer FA (ed) Proceedings on wood combustion, Environmental Assessment, New Orleans. Feb. 1981, US EPA 600-9-81-029

McMahon CK, Bush PB, Woolson EA (1985a) The release of copper, chromium and arsenic from the burning of wood treated with preservatives. Proceedings of the 78th Annual Meeting of the Air Pollution Control Association in Detroit, Michigan. June 16-21, 1985. Paper No. 85-56.3

McMahon CK, Clements HB, Bush PB, Neary DG, Taylor JW Jr (1985b) In: Pesticides released from burning treated wood. Proceedings of the 8th Conference on Fire and Forestry Meteorology, Detroit, MI, April 29-May 2, 1985. pp 145-154

McMahon CK, Tsoukalas SN (1978) Polynuclear aromatic hy- drocarbons in forest tire smoke. In: Carcinogenesis, Vol. 3, Polynuclear Aromatic Hydrocarbons. Raven Press, NY. pp 61-73

Mullison WR (1981) Public concerns about the herbicide 2,4-D. Dow Chemical Co, Midland, Michigan

National Academy of Sciences-National Research Council (1977) Drinking water and Health, Vol. 1. Report of the Safe Drinking Water Committee, Washington DC, 939 pp

Peters HA, Croft WA, Woolson EA, Darcey BA, Olsen MA (1983) Arsenic, chromium, and copper poisoning from burning treated wood. New England J Med 308(22):13601361

USDA Forest Service (1984) Pesticide Background Statements: Volume 1. Herbicides. Agriculture Handbook No. 633. Washington, DC

Watson CC (1958) The contamination of bacon by arsenic from smoke derived from preservatized wood. New Zealand J Sci 1(3):361-368

Weed Science Society of America (1983) Herbicide Handbook, 5th edn. Champaign, Illinois

Yamasaki H, Kuwata K, Mlyamoto H (1982) Effects of ambient temperature on aspects of airborne polycyclic aromatic hydrocarbons. Environ Sci Technol 16(4): 189- 194

Manuscript received July 25, 1986 and in revised form November 14, 1986. 